DOI: https://doi.org/10.31933/dijemss.v3i1

Received: 19 September 2021, Revised: 19 October 2021, Publish: 27 october 2021

\begin{tabular}{|c|c|c|}
\hline DINASTIS & $\begin{array}{l}\text { DIJEMSS } \\
\text { DINASTI INTERNATIONAL JOURNAL } \\
\text { OF EDUCATION MANAGEMENT AND } \\
\text { SOCIAL SCIENCE }\end{array}$ & $\begin{array}{r}\text { https:I/dinastipub.org/DIJEMSS } \\
\text { editor@dinastipub.org } \\
08117401455 \square\end{array}$ \\
\hline
\end{tabular}

\title{
LEADERSHIP MANAGEMENT IN IMPROVING THE QUALITY OF SERVICES IN PRIVATE UNIVERSITY (STUDY AT STAI AL- MA'ARIF, ASHANTA, AL-AZHAR JAMBI PROVINCE)
}

\author{
Hindun Hindun ${ }^{1}$, Norainun Norainun ${ }^{2}$, Yusraini Yusraini ${ }^{3}$, Ely Surayya ${ }^{4}$ \\ 1) UIN Sulthan Thaha Saifuddin, Jl. Jambi Ma. BulianKM.16 Sei. Duren Kabupaten Muaro \\ Jambi, 36363, Indonesia \\ 2) Sekolah Tinggi Agama Islam Al-Ma'rif Sarolangun \\ 3) UIN Sulthan Thaha Saifuddin, Jl. Jambi Ma. Bulian KM.16 Sei. Duren Kabupaten Muaro \\ Jambi, 36363, Indonesia \\ 4) UIN Sulthan Thaha Saifuddin, Jl. Jambi Ma. Bulian KM.16 Sei. Duren Kabupaten Muaro \\ Jambi, 36363, Indonesia
}

\section{Corresponding Author: Hindun Hindun ${ }^{1}$}

\begin{abstract}
Leadership Management in Improving Service Quality in private universities in Jambi Province which is the target of research is under the Regional Kopertais Environment of UIN Sulthan Thaha Saifuddin Jambi. The quality of service in an organization is the main focus, considering that services that can be carried out effectively and efficiently are a dream for all customers, and the goal of the organization itself. In this study, the researcher used a qualitative-naturalistic approach. Through this qualitative approach, it is hoped that an overview of leadership management and service improvement will be raised. The naturalistic approach demands data collection in a natural setting. The method used in collecting data in the field is the method of observation, interviews and documentation. The results of this study indicate that the implementation of service quality carried out by the Three Private STAIs in the Kopertais Region XIII Jambi City environment have both implemented the eight standards as specified in the planning. However, there is a very significant difference between Ashanta and Al-Azhar Private STAI and Al-Marif Private STAI. Of the three STAIs, the one that is superior is the Al-Ma'rif Private STAI, with evidence that can be seen from the number of students quite a lot, and the majority of the teaching staff are S2 qualified and some are even S3 qualified. When viewed from the satisfaction of service quality from customers, Al-Ma'rif Private STAI has the advantages of the three Private STAIs that are the targets of researchers, satisfaction indicators such as learning facilities and infrastructure are independent and have their own. In addition, the management of financing is more organized and transparent from the Foundation and the Chairperson of the Foundation to their subordinates. Payment of honorarium for staff and lecturers in accordance with the provisions specified and paid on time.
\end{abstract}

Keywords: Management Leadership, Quality of Service 


\section{INTRODUCTION}

Management comes from English to manage which means to organize, administer, or manage (Saefullah, 2012). According to Ricky W. Griffin, management is a set of activities that include: planning and decision making, organizing, directing, and controlling carried out directly by an organizational resource (people, money, physical objects, and information) (Ricky W. Griffin, 1997). Waggner and Hollenbeck, management is a process of planning, organizing in order to achieve goals through the division of labor. From this definition, there are several points, namely first, management is a process, a flow of activities. Not something that can be achieved once for everything. Second, managerial activities affect the behavior of members of the organization and the organization itself (Wagner, Jhon A. III and John R. Hollenbeck, 1995).

Nanang Fattah, management is often defined as science, tips, and professions. It is said to be a science by Luth Gulick in Nanang Fattah, because management is seen as a field of knowledge that systematically seeks to understand why and how people work together. It is said as a tip by Follet that it is still in Nanang Fattah, because management achieves goals through ways by arranging other people to carry out tasks. Seen as a profession because management is based on special skills to achieve a manager's achievement, and professionals are required by a code of ethics (Nanang Fatah, 1996). Malay Hasibuan quoted by Saefullah, management is the science and art of managing the process of utilizing human resources effectively, which is supported by other sources within the organization to achieve certain goals. In management, there are two systems, namely organizational systems and administrative systems (Saefullah, 2012). The leader must master the ways of leadership, have leadership skills so that he can act as a good leader, for that, among others, he must master how to: make plans together, invite members to participate, provide assistance to group members, foster group morality. jointly make decisions, avoid "working on the group and working for groups" and develop "working within the group" sharing and handing over responsibilities and so on. To acquire these skills, you need experience and therefore the leader must really get along, cooperate and communicate with the people he leads. The important thing is not only to know, but to be able to implement (Anoname, 2010).

A leader is someone who has certain skills that can influence his followers to cooperate towards achieving the goals that have been set. Therefore, it is clear that the leader can have various advantages, abilities and compared to other members. With the advantages he has, the leader can have the authority so that his followers obey him. These advantages are various, including moral advantages, work spirit, skills, intelligence, tenacity, and so on (Daryanto, 2013). The experience of many organizations or institutions shows that an appraisal system, a good work performance appraisal system, is very useful for various purposes:

- Encouraging increased work performance. By knowing the results of work performance.

- As a decision-making material in the provision of rewards. 
- For the sake of transfer of employees/employees, past work achievements of a person are the basis for making transfer decisions for him in the future, regardless of the form of the mutation, such as promotion, transfer of duties, transfer of territory or demotion.

The concept of leadership basically comes from the word pimpin which means to guide or demand. From the word lead gives birth to the verb leading which means to guide or guide and the noun the leader is the person who functions to lead or the person who functions to lead or the person who guides or guides. While leadership is a person's ability to influence others in achieving goals. The qualities that underlie leadership are leadership skills. At the very least, it can be said that skills include three basic skills, namely: 1) Individual understanding skills, which means knowing that every human being has a different motivational power at different times and in different circumstances 2) The ability to inspire and inspire 3) The ability to take action in a way that can develop a motivating and motivating atmosphere at the same time that can inspire. According to Tatang M Amirin quoted by Eka Prihatin (Eka Prihatin, 2011) he has another opinion, stating that leadership skills include three main underlying elements, namely: 1) A leader must have social perception abilities 2) Ability to think abstractly (ability in abstract thinking) 3) Have emotional stability.

The underlying control carried out by a leader has three ways: first, feed forward control which is carried out before work begins. The goal is to anticipate possible problems that will arise and take preventive actions, both concurrent controls Namely focusing control activities on what is running or the process of carrying out work, the third is feedback control or also called post-action controls, namely measurements and improvements are carried out after the activity is carried out (Nana Syaodihsukmadinata, Ayi Novi Jami'at dan Ahman, 2006). According to House's version of the path-goal theory, it includes four main types or styles of leadership which are described as follows:

- Directive leadership, this type is the same as the autocratic leadership model of Lippitt and White. Subordinates know exactly what is expected of them and specific directions are given by the leader.

- Supportive leadership. This leadership model has a willingness to self-explanatory, friendly, approachable and has genuine humanitarian concern for his subordinates.

- Achievement-oriented leadership. This leadership style sets a set of goals that challenge participating subordinates.

According to Martin J Canon quoted by Syaiful Sagala, leadership is the ability of superiors to influence the behavior of subordinates and group behavior in organizations. This opinion is based on:

- There are those who emphasize the personality, abilities and abilities of the leader,

- Emphasize the activities, position and behavior of the leader and,

- Emphasize the process of interaction between leaders and subordinates in certain situations (Miftah Thoha, 2012). 
The quality and quantity of human resources in an organization should be adjusted to the needs of the organization concerned to be effective and efficient in supporting the achievement of goals. Appropriation of employees or employees must also be adjusted to their desires and skills, so that their work motivation and discipline will be better, as well as effective in supporting the realization of organizational goals (Sedarmayanti, 2009). Productivity and performance are parts that must be considered in Human Resources Management (HR). Successful managers must have the ability to improve the performance and productivity of their employees. Both are very important in determining the sustainability of entrepreneurial activities and their work (Triton PB, 2009).

\section{LITERATURE REVIEW}

Service Quality

Quality improvement is inseparable from the concept of quality education, because improving the quality of education is determined by improving aspects/indicators of the quality of education itself. Until now there is no clear agreement on the definition of quality of education. The literature that discusses the quality of education is still relatively limited. Sallis argues that the concept of quality can be viewed in terms of absolute and relative, rare and expensive are two important values in the concept of quality. Meanwhile, from a relative point of view, quality has two aspects, namely conformance to specifications and meeting customer needs. This statement shows that the concept of quality is not easy to build, because these two meanings of quality give the meaning that quality depends on the person giving the assessment. In this case, the quality according to one person is not the same as according to others.

The American Society for Quality Control (ASQC) as quoted by Lindsay and Petrick defines quality as follows, quality as the totality features and chaccteritics of a product or service that bears on its ability to satisfy a given need (William M. Lindsay dan Joseph A. Petrick, 1997). According to Lindsay and Petrick, quality includes dimensions: performance, features, reliability, conformance, durability, serviceability, aesthetics and perceived quality (Ibid, Hal 55). Furthermore, Lindsay and Petrick, provide dimensions of service quality which include: time, timeliness, completeness, courtesy, consistency, accessibility, accuracy and responsiveness.

The definition of quality put forward by Lindsay and Petrick shows that quality states the overall fulfillment of the characteristics set for a product and service. Product quality is determined by the fulfillment of characteristics such as appearance, characteristics, feasibility, suitability, durability, repairability, aesthetics and what is perceived as quality. While the dimensions of service quality are waiting time, completeness, availability, consistency, accessibility, accuracy and sensitivity to customer needs. Quality is defined as the fulfillment of requirements. In the context of services, the requirements in question can include dimensions that service can be felt/enjoyed, whether or not the service complies with the service, whether or not it is sensitive to customer requests, whether or not the service is 
carried out according to procedures, and whether or not the service is provided as well as receiving service (Robert Kreitner, 1999).

Analyzing the basic understanding of quality and service put forward by Kreitner, if it is seen in education, then education itself can be viewed from two sides, namely products and services. In terms of product quality, there is a change in behavior to the input process after following the learning process within a certain period of time. In terms of service, teachers, the community and the world of work receive services that meet the service dimension.

According to Mastuhu, Quality is a dynamic term that keeps moving; If it moves forward, the quality is said to be getting better, if it moves backwards, the quality is said to have decreased. Quality can be interpreted as superiority or excellence, which is exceeding the general standards that apply. Something is said to be of quality if there is a match between the conditions possessed by the desired object and the intention of the person who wants it. For example, the quality of the learning process matches what students expect; the further beyond what is expected, the more qualified, if the opposite happens, the less qualified (Mastuhu, 2004). Panasaruman quoted by Shahin, Service quality is the difference between the expected service and the service received. If the expectation is greater than the performance, then the perceived quality is smaller than the satisfaction, because consumer dissatisfaction occurs (Shahin, 2007).

The Accounts Commission identified 10 service quality factors, namely 1) access to the ease and convenience of obtaining services, 2) communication, namely keeping consumers always obtaining information in a language that is understood and heard by consumers, 3 ) competence, namely having the skills and knowledge of the services provided. given, 4) respect, which includes courtesy, respect, consideration, and friendliness from all levels of staff, 5) credibility, which includes trust, reputation and image, 6) reliability, providing consistent, accurate, and reliable services, and providing, service as promised, 7) responsiveness, is having the willingness and readiness to provide services when needed, 8) security, including physical security, finance and confidentiality, 9) physical evidence, including physical aspects of services such as equipment, facilities, staff and appearance, 10) understand consumers, namely knowing the personal needs of consumers and recognizing repetition consumers (Anoname, 2007).

Referring to the background of the problem above, the main question in this research is "why STAI in Jambi City has not provided optimal service satisfaction to customers? Thus, the sub-topics in this study are as follows: What is the form of service planning in 3 (three) STAI Jambi City?, How is service implementation in 3 (three) Jambi City STAI?, How is the analysis of service satisfaction to customers carried out by STAI Jambi City?. The research objective is to know the form of planning, implementation, and analysis of service satisfaction in 3 (three) STAI Jambi City. 


\section{METHOD}

In this study, the researcher used a qualitative-naturalistic approach. Through this qualitative approach, it is hoped that an overview of leadership management and service improvement will be raised. The naturalistic approach demands data collection in a natural setting. With this concept, the researcher strives for the presence of the researcher not to change the situation or behavior of the person being studied. The method of collecting data in the field is the method of observation, interviews and documentation.

\section{Empirical Data}

\section{Forms of Service Planning in Three Private STAIs in Jambi City}

Talking about service quality in an organization is the main focus, considering that services that can be carried out effectively and efficiently are the desire of all customers, and the goals of the organization itself. The three private STAIs in Jambi Province that were the target of the research were under the Regional XIII Kopertais Environment of UIN Sulthan Thaha Saifuddin Jambi. Therefore, according to the documentation data that researchers can collect when conducting research, it is found that the form of service planning from the three STAIs mentioned above is inseparable from the standards set by the Government and Kopertais themselves, as follows:

\section{Graduate competence standard}

Commitment to service improvement and academic quality improvement in the context of producing Islamic higher education graduates who have quality standards for quality graduates (alumni), then undergraduate candidates must at least have the following competencies:

a. Mastery of basic religion (tawhid, practical worship, fiqh, and morals) as well as being able to read and understand the verses of the Qur'an and hadith and their interpretation.

b. Memorize Juz Amma or at least short letters, namely Al-Ghasiah, Al-A'la, Adh-Dhuha to Surah An-Nas.

c. Mastery of IT (Ms Word, Ms Excel, Powerpoint, E-Learning, and Website maintenance).

d. Having the ability as a lecturer, preacher, imam, bilal, organizer of the corpse, as well as reading and writing verses of the Qur'an correctly.

e. Minimum Grade Point Average (GPA) is 3.00.

f. Mastering competencies according to the scientific field.

Standard Content (Curriculum)

The content standard is the scope of the material and the level of competence as outlined in the criteria for graduate competence, study materials, subjects, and learning syllabus that must be met by students. The importance of this curriculum considering the demands of global human resources and the changes that occur in the era of globalization require adjustments in all aspects of people's lives, and strategically must be able to answer the demands of the standard needs of stakeholders and the user community. The curriculum offered, apart from starting from the roots of Islamic sciences, culture, and society, also 
emphasizes aspects of personality, expertise, skills, professionalism, behavior, and social interaction that have not been touched by the comprehensive Islamic College curriculum.

In the content aspect, there is a condensation of courses, where there are no longer loose change courses that are considered less relevant and no longer support the interests of students, especially towards competence and professionalism according to work skills and post-education service.

\section{Standard Process}

Process standards are standards related to the implementation of learning in educational units to achieve graduate competency standards supported by micro teaching standards and real work lecture standards. This learning process is an effort in order to improve the learning process which includes various understandings of the system in the learning process, which involves the quality of lecturers, curriculum, learning processes, and other supports, such as administrative staff/staff, libraries, laboratories, and others. It aims to develop and improve learning, especially to promote or generate student motivation and selfconcept.

\section{Educator Standard}

The standard of educators is the existence of criteria for pre-service education and physical and mental feasibility, as well as education and position. This is of course related to the demands of academic qualifications, competencies, and certification of educators. The academic qualification in question is a diploma of education level that must be owned by a lecturer, in this case it is required to have a minimum diploma of S2. A lecturer must also have competence, namely a set of knowledge, skills, and behaviors that must be possessed, internalized, and mastered by the lecturer in carrying out his professional duties, which include pedagogic competence, personality competence, social competence, and professional competence. Certification is the process of providing educator certificates for teachers and lecturers, as formal evidence given to them as professionals.

\section{Facilities and Infrastructure Standards}

Standards for facilities and infrastructure (learning resources) are standards relating to minimum criteria regarding study rooms, places to exercise, places of worship, libraries, laboratories, workshops, playgrounds, recreation areas, and other learning resources, which are needed to support the learning process. , including the use of information and communication technology. The importance of optimizing in utilizing these learning resources, namely the availability of compulsory books, complementary books, handbooks, source books (references), and reading books, as well as the provision of educational media, such as teaching aids, electronic media such as OHP, projectors, tape recorders, to even simple media.

\section{Management Standard}


Management standards (education services) are standards related to the planning, implementation, and supervision of educational activities in order to achieve efficiency and effectiveness in the provision of education. This includes the management of education personnel or the management of educational personnel which aims to utilize the educational staff effectively and efficiently.

\section{Financing Standard}

Financing standard is a standard that regulates the components and the amount of operational costs for educational units. It can be understood that in the education system, the financing aspect will determine the continuity of an educational institution. Educational institutions that grow and develop will certainly have a big contribution to the progress of the nation and state.

\section{Educational Assessment Standards}

Educational assessment standards are standards related to the mechanisms, procedures, and instruments for assessing student learning outcomes. Based on the results of the documentation above, it can be concluded that the form of service planning from the three STAIs that were targeted by researchers, in this case, the Regional XIII Kopertais of UIN Sulthan Thaha Saifuddin Jambi imposed the same procedure between students of UIN Sulthan Thaha Saifuddin Jambi and Private Islamic Colleges (Islamic High School/High School of Tarbiyah Sciences), so that overall they can achieve the predetermined graduation standards. This problem is reinforced by the results of the researcher's interview with one of the Deputy Chairmen of STAI Al-Ma'arif Jambi, whose initials are JL. He said that the form of service planning at STAI Ma'arif is the same as other PTAI, both public and private. However, there are differences in several respects, such as in terms of financing, because in private STAI the financing is from non-governmental organizations which are more autonomous, and are assisted by the government. Meanwhile, the state is financed by the Government assisted by non-governmental organizations.

Another statement was also made by one of the Deputy Chairpersons of Ashanta Private STAI with the initials MS saying that all organizations want quality services that are effective and efficient. However, in private STAIs, especially in Ashanta, there are very many shortcomings of the eight standards that have been determined by the government, for example, facilities for students to study, still borrowed and not owned by themselves, learning infrastructure is still inadequate, the number of students is still small, because STAI Ashanta is located in the middle of the school. In the middle of Public Universities which have qualified service quality, the funding is very inadequate. Alhamdulillah, even though the STAI condition is like this, it has been accredited $C$, meaning that students studying at STAI are guaranteed the validity of their diplomas.

The next statement was put forward by one of the Deputy Chairpersons of STAI AlAzhar with the initials AB saying that the service planning of STAI has been structured as other Private STAIs in the Kopertais Region XIII Jambi Province. However, it is recognized 
that its services in several respects are very inadequate, such as the very small number of students, this case is the same as the Ashanta Private STAI, the location is in the middle of very qualified public universities, namely the State Islamic University, Jambi State University and Batang Hari University. Jambi and Jambi School of Technology and Information. In addition, STAI only has two PAI and PAUD study programs, as well as facilities and infrastructure that are still united with the Al-Azhar Integrated School, meaning that it still does not have its own building specifically for STAI Al-Azhar.

Based on the documentation data and the results of the researcher's interview above, it can be understood that the form of service planning in the Private STAI which is the target of the researcher does not meet the standards set by the government and Regional Kopertais XIII Jambi Province. Therefore, the management of Private STAIs, continues to strive to realize good services in accordance with government standards, in the current era of globalization Private STAIs must be able to compete with other private universities.

\section{Implementation of Service Quality in Three Private STAIs (Al-Ma'rif, Ashanta, and Al- Azhar) Jambi City}

Based on the results of research documentation data on the implementation of service quality in the three private STAIs targeted by researchers, it is indicated that the Service Quality System is a program intended to perfect and improve the quality of academic activity implementation through the achievement of higher education management standards. The implementation of this quality assurance shows that the achievement of standards that have been declared by each Islamic Higher Education has the following foundations and objectives:

\section{Base}

Government Regulation Number 19 of 2005 Chapter XV concerning Quality Assurance Article 91 and Article 92.
Aim
1) Strive for the implementation of a quality control group in the field of learning.
2) Supporting the acceleration of academic achievement.
3) Assist in the fulfillment of the responsibilities of each Islamic Higher Education institution in carrying out academic activities as management control over academic quality. This goal is intended so that the implementation of the learning process at each Islamic Higher Education institution is truly controlled for its quality in order to reach Islamic Higher Education in accordance with the National Education Standards.

\section{Scope of Quality Assurance}

1) Input (input), namely students, lecturers, administrative staff, finance, infrastructure, information.

2) Process, namely study program, learning process, and assessment of learning outcomes, management system.

3) Output (output), namely graduates, research, community service. 
4) Outcome (impact), namely good relations with stakeholders, graduate users, and related institutions.

\section{Preparation for the Implementation of the Service Quality System, namely:}

1) Conducting preliminary research on the objective conditions of the implementation of academic learning within each institution of Islamic Higher Education.

2) Organizing the socialization of administrative provisions for the implementation of academic surveys.

3) Organizing academic quality development activities in each Islamic Higher Education through conducting academic surveys on the implementation of the learning process by all lecturers.

4) Conducting internal improvement of academic learning in each Islamic Higher Education through the implementation of induction programs for lecturers.

Establish cooperation or networking with other institutions to improve the academic quality of each Islamic Higher Education.

The results of the researcher's documentation data above, it can be understood that the implementation of service quality in the three private STAIs targeted by researchers has the basis stated in the Act. However, in its implementation in each STAI, researchers still find discrepancies with the service standards that have been determined, as the results of the researcher's observation data are as follows:

\section{Implementation of Service Quality Standards for Student Graduates}

STAI Ashanta Jambi City, Implementation of service quality at STAI in accordance with the conditions and situation of STAI itself. Ashanta Private STAI is experiencing many shortcomings, such as student graduation is still very minimal, so far it has not reached 250 people, as well as the results of the achievement index are still in the medium category, none of them have reached the commulaude. In addition, the number of students who are still in the learning process is only $35 \%$. The majority of students come from outside the city of Jambi, only $15 \%$ and some come from outside the province of Jambi $25 \%$, meaning that the service to students is not optimal. This problem is strengthened by the results of the researcher's interview with one of the management staff at the Ashanta Private STAI with the initials DK saying that the service to students is still not optimal, because the facilities where students study are also limited. Therefore, there are not so many students entering the Ashanta Private STAI, and it is also difficult to find students, because students prefer State Universities and Public Universities that are qualified next to the STAI Ashanta building.

STAI Al-Azhar Jambi City, The implementation of the quality of student graduation services is also not much different from the Ashanta Private STAI, both in terms of the number of students and from their graduation. The number of students is very small, because the location is more adjacent to the Public Universities in the Kopertis Environment which is united with the Al-Azhar integrated school foundation itself, the majority of students who have graduated are from staff and service clinics who have not had a bachelor's degree (S1) 
in Al-Azhar. itself, which is very small at only $25 \%$. This means that the quality of service to students is also not adequate as in other private STAIs such as Al-Ma'rif. This problem is reinforced by a statement from one of the management staff with the initials AB stating that it is very aware that the quality of service to students is not adequate as expected. Because this Private STAI is united with Public Universities in the Kopertis Environment which has English and Early Childhood Education study programs, besides that it is also side by side with General Universities (UNJA) and Religion (UIN). Therefore, it is very difficult to find students to study at this Al-Azhar Private STAI.

Al-Ma'arif Private STAI Jambi City, the implementation of the quality of student graduation services, in the observations of researchers is quite capable, when compared to Ashanta and Al-Azhar Private STAIs. Because the location is quite far from State and Private Public Universities and State Islamic Universities, the advice is sufficient to accommodate a large number of students. For this reason, the number of graduating students already has a cumulative GPA. This means that the Al-Ma'arif Private STAI in Jambi City can be said to have almost met the predetermined standards. This problem is reinforced by a statement from one of the managers with the initials RN saying "Alhamdulillah at the Al-Ma'rif Private STAI, there are already graduating students who have achieved the cumulative Achievement Index, and the number of students who graduate each year has reached 250 people, while in the learning process amounted to 450 students. Therefore, Al-Ma'rif's private STAI accreditation can achieve a B value.

\section{Implementation of Service Quality Standard Content (Curriculum)}

The implementation of service quality in terms of the curriculum at the Three Private STAIs that were the targets of the research had both carried out as specified in the Regional XIII Kopertais guidebook at the State Islamic University of Sulthan Thaha Saifuddin Jambi. Curriculum development is an activity to produce a curriculum at Islamic Higher Education or a process that links one component with other components to produce an Islamic Higher Education curriculum. Which has a foundation such as:

\section{Law of the Republic of Indonesia Number 20 of 2003 concerning the National Education System (Chapter X Article 36):}

1) Curriculum development is carried out with reference to national education standards to realize national education goals.

2) The curriculum at all levels and types of education is developed with the principle of diversification according to the education unit, regional potential, and students.

3) The curriculum is prepared according to the level of education within the framework of the Unitary State of the Republic of Indonesia by taking into account: increasing faith and piety, increasing noble character, increasing the potential, intelligence, and interests of students, diversity of regional and environmental potentials, demands for regional and national development, demands for world of work, development of science, technology, and art, religion, dynamics of global development, national unity and national values. 
4) Provisions regarding curriculum development as referred to in paragraph (1), paragraph (2), and paragraph (3) shall be further regulated by Government Regulation. (1) Government Regulation of the Republic of Indonesia Number 19 of 2005 concerning National Education Standards (Article 9 ): The basic framework and structure of the Higher Education curriculum is developed by the relevant tertiary institution for each study program. (2) The Higher Education Unit Level Curriculum must contain the subjects of Religious Education, Citizenship Education, Indonesian Language, and English. (3) In addition to the provisions as referred to in paragraph (2), the Higher Education Unit Level Curriculum for Bachelor and Diploma programs must include subjects lectures containing personality, culture, as well as statistics, and/or mathematics courses.

\section{Purpose}

- The direction to be achieved in the education and teaching process is getting clearer.

- Education and teaching become dynamic with problem solving that can be directly handled at the level of Islamic Higher Education.

- Islamic Religious Colleges can manage the curriculum according to their needs.

- Empowerment of potential education personnel.

- Education and teaching resources are becoming more effective and efficient.

- The use of information and multimedia sources for education and teaching is increasingly targeted and programmed.

\section{Higher Education Unit Level Curriculum Development Activities}

Curriculum Development Activities at the Higher Education Unit Level include planning, implementing, monitoring and evaluating, as well as improving the curriculum at Islamic Higher Education.

\section{Basic View of Islamic Higher Education Curriculum Development}

a) The mission of Islamic Higher Education is to develop Islamic sciences and religious behavior that is loyal to Islam.

b) The mission is to prepare prospective graduates who are able to integrate professionalism, academic intellectuality, and the personality of ulama (scholars who are scientists and pious scientists).

c) Mission to prepare graduates who are competitive and comparative.

d) Mission of fostering and developing Islamic society in various sectors.

\section{Operational Reference for Higher Education Unit Level Curriculum Preparation}

a) Increasing faith and piety and noble character

b) Increased potential, intelligence, and interests in accordance with the level of development and abilities of students

c) Diversity of regional and environmental potentials and characteristics

d) Regional and national development demands 
e) The demands of the world of work

f) The development of science, technology, and art

g) Religion

h) The dynamics of global development

i) National unity and national values

j) Socio-cultural conditions of the local communityGender equality

k) Characteristics of the education unit

\section{Higher Education Unit Level Curriculum Components}

a) Higher Education Unit Level Curriculum Objectives

b) Structure and Content of Higher Education Unit Level Curriculum

c) Education Calendar

\section{Syllabus Development}

The syllabus is a written design developed by the lecturer as a lesson plan for one semester. Syllabus is the professional responsibility of lecturers to institutions, colleagues, students, and society. Syllabus to answer what competencies must be mastered by students, how to achieve them, and how to find out their achievements.

Syllabus development is an effort of curriculum development and implementation, empowerment of educators, utilization of educator resources, and the use of various sources of information in learning. The Syllabus Development Principles are as follows:

1) Syllabus Development Principle
a) Scientific
b) Relevant
c) Systematic
d) Consistent
e) Adequate
f) Actual and Contextual
g) Flexible
h) Thorough

2) Syllabus Development Steps
a) Analysis of Graduation Standards and Competencies
b) Formulation of Learning Objectives and Teaching Materials
c) Formulation of Learning Activities
d) Rating
e) Material Source
f) Time Allocation

3) Syllabus Development Strategy
a) Planning
b) Implementation
c) Repair
d) Consolidation
e) Syllabus Assessment 
4) Syllabus Development Component

a) Course Competence: a minimum (adequate) statement of knowledge, skills, attitudes, and values reflected in everyday life in one course.

b) Basic Competence: a minimal (adequate) statement of knowledge, skills, attitudes, and values that are reflected in everyday life in certain aspects of a course.

c) Main Materials: subjects and sub-subjects to achieve basic competencies.

d) Learning Activities: knowledge or activities that need to be carried out by students to achieve basic competencies.

e) Indicators: characteristics, traits, actions, or responses that must be carried out or displayed by students, to show that a student already has certain basic competencies that will be measured in the assessment.

f) Assessment: the usual way to determine the quality of individual or group performance and interpretation of measurement data.

g) Time Allocation: a description of the time needed to carry out the learning process.

h) Learning Resources: teaching materials, books, objects, or people that can be used as

- resources in the process of achieving competence.

- materials, strategies, evaluations, learning resources, assessments, and lecture administration provisions.

- Collect references of at least 15 book titles and study them carefully to formulate the material to be included in the Lesson Plan.

- Consultation with senior lecturers (a consortium of course lecturers).

- Submit the Learning Implementation Plan to the Head of Department or Head of Study

\section{Program before entering lectures.}

Furthermore, the development of teaching materials is information, tools, and texts that are needed by lecturers or educators for planning and studying the implementation of learning. Teaching Materials or Learning Materials which broadly consist of knowledge, skills, and attitudes that students must learn in order to achieve predetermined competency standards. In detail, the types of learning materials consist of knowledge (facts, concepts, principles, procedures), skills, and attitudes or values.

Form of Teaching Materials

a) Printed materials, such as hand outs, books, modules, brochures, leaflets, wallcharts.

b) Audio visual, such as video or film, VCD.

c) Audio, such as radio, cassette, audio CD.

d) Visuals, such as photos, drawings, modules, or mockups.

e) Multi media (interactive CD, computer based internet).

f) Teaching Material Development Tips

g) Utilization of Information and Communication Technology.

h) Power Point Program.

i) Determination of visualized competence. 
j) Finding sources of teaching materials through VCDs, CDs, CD rooms, digital cameras, handy cams, and the internet.

Development of Active, Creative, and Innovative Learning Strategies is a series of activities or steps in learning to achieve learning objectives. The development of learning strategies is an effort to implement planned learning models in order to realize effective learning. Effective learning models include active learning, independent learning, cooperative and collaborative learning, and general learning.

Related to the Development of Learning Evaluation System, namely:

a) Assessment is the application of various methods and the use of various assessment tools to obtain information about learning outcomes and competency achievement.

b) The purpose of the assessment includes the principles of tracing, examining, finding, and inferring.

c) The principles of assessment contain elements of being valid, educating, competencyoriented, fair, open, sustainable, comprehensive, and meaningful.

d) The assessment function contains elements of motivation, complete learning, indicators of teaching effectiveness, and feedback.

e) Assessment techniques can be done through tests (multiple choice, true-false, matchmaking, short entries, descriptions), performance, assignments (projects), and portfolios.

\section{Implementation of Service Quality Standards for Educators}

The majority of the teaching staff (lecturers) who teach at three private STAIs in the Kopertais Region XIII who are the research targets have master's qualifications, even 2\% have doctoral qualifications. researchers with several lecturers such as: Lecturers who teach at the Ashanta Private STAI, with the initials IW stated that the quality of services related to teaching staff (lecturers), there are already doctoral qualifications, but on the other hand there are also study programs that still do not meet the power of lecturers, considering that one study program must have 6 people. permanent lecturer. However, this shortcoming will still be fulfilled in the future, because the qualification of master's degree lecturers has become the needs and demands of the times in the current era of globalization. Another statement is that the lecturer who teaches at the Al-Azhar Private STAI, with the initials MR, stated that $3 \%$ of this STAI has master's degree, but there is still a shortage of lecturers to fulfill the strength of the study program, currently they are still borrowing lecturers who teach at public universities under the auspices of the Foundation. Al-Azhar. This means that STAI Al-Azhar has not met the standards of educators that have been determined by the government. Furthermore, it was also stated that one of the private STAI lecturers, Al-Ma'arif, with the initials MR, said that thank God the lecturers who teach have met the S2 qualification standards, even $2.5 \%$ have doctoral qualifications, besides that, the needs for study programs have also been met, meaning that The teaching staff at the Al-Ma'rif Private STAI have met the standards set by the government, namely at least one study program has 6 lecturers with master's qualifications. 


\section{Implementation of Service Quality Standards for Facilities and Infrastructure}

Regarding the implementation of the quality of service facilities and infrastructure at the Three Private STAIs that the researchers examined, there are also very far differences between Ashanta, Al-Azhar and Al-Ma'rif Private STAIs. Even though when viewed from the location both are in the city of Jambi. However, the Al-Marif Private STAI has its own facilities and adequate infrastructure. On the other hand, STAI Ashanta and Al-Azhar are still not independent and are still borrowing.

\section{Implementation of Service Quality Management Standards}

The quality of management services is also that the Al-Ma'rif Private STAI is superior to the two Ashanta and Al-Azhar Private STAIs. If we look at the governance of the private STAI Al-Ma'rif, it is more appropriate to place according to the competencies possessed by each of its staff, while for the Private STAI Ashanta and Al-Azhar still lack expert staff and place it not according to their expertise.

\section{Implementation of Financing Standard Service Quality}

The implementation of services regarding financing is both managed by the Chairman of the Foundation, but the management is more effective at the Al-Ma'rif Private STAI. While STAI Ashanta and STAI Al-Azhar are not effective, because based on information that can be gathered through interviews from one of the deputy heads of 2 Private STAIs with the initials MR and MD, the researcher can conclude that the existing funding is not clear in its use. Because the money collected from student tuition fees just runs out, even the management staff and lecturers who teach have not been given honoraria for a long time. Even though the number of students is small, if managed effectively it will certainly produce good results.

\section{Implementation of Service Quality Standards for Educational Assessment}

Based on the documentation data that the researchers managed to collect, that the AlMarif Private STAI is also superior to the two Ashanta and Al-Azhar Private STAIs. Its superiority is proven by the value of the accreditation of each study program B, while the Ashanta and Al-Azhar Private STAIs are still worth C. Therefore, policies in the field of education and teaching are oriented towards improving the quality and professionalism of academic services, expansion and access to obtain higher education, improving and strengthening the curriculum, establishing and managing the legality of study programs, improving the quality of standardized inputs, processes, and learning outcomes, developing and improving educational professional certification programs, legal advocacy, Islamic symbols, and Islamic studies, as well as strengthening networking /webworking with local/regional, national, and international institutions.

The results of the data documentation, observations and interviews above, it is very clear that the implementation of service quality from Government Regulation No. 19 of 2005 concerning National Education Standards carried out by Private Higher Education Institutions (STAI) in the Kpertais Region XIII environment which is the target of researchers, to 
Ashanta and Al-Azhar Private STAIs still do not meet 8 National Education Standards, while Al-Ma'rif Private STAIs have started to meet 8 National Education Standards, with one proof that judging from the facilities they are independent (own) as well about the infrastructure is already adequate.

\section{Analysis of Service Satisfaction to Customers conducted by STAI Jambi City}

Observing the results of the implementation of service quality carried out by the Three Private STAIs in Jambi City, customer service satisfaction can be felt by customers at STAI Al-Marif Jambi City. Because according to the observations of researchers, there are several indicators that make customer satisfaction, such as 1) the location on the outskirts of Jambi City is far from competitors with other universities 2) The facilities and infrastructure are owned by themselves, 3) The number of students is quite large, 4) The teaching staff is qualified for Masters some even have S3. 5) Relations with local governments are quite good. In addition, there are also several lecturers with the status of civil servants who are willing to devote themselves both as officials and as other management personnel.

Associated with two private STAI Ashanta and Al-Azhar, which makes the service less satisfied indicated; 1) location in the middle of Jambi City which is side by side with qualified public and state and private universities, 2) facilities and infrastructure used for learning not their own property (borrowing) 3) The number of students is very small, 4) The teaching staff still does not meet the qualifications, even though they have qualified S3 at the Ashanta Private STAI, but have the status of selfless service. 5) Financial management is still chaotic and not structured systematically. In addition, the lack of enthusiasm from managers to move forward and compete in the current era of globalization. It means standing up like a squirrel with the help of growing up, life is reluctant to die, doesn't want to.

Based on data from an interview with one of the lecturers at Ashanta Private STAI with the initials HS, he stated that the progress of an organization is largely determined by a leader, if the leader is not enthusiastic, the subordinates will also be less enthusiastic. Therefore, especially the Ashanta Private STAI, there are many shortcomings, ranging from the difficulty of finding students to the management which is also not as organized as expected. An example of financial management that is not transparent in its use, even if the amount is small, if used properly will produce good results. Another statement was also made by one of the lecturers who teaches at the Al-Azhar Private STAI Jambi City with the initials AZ, saying that it is very difficult to achieve service quality that satisfies customers at this STAI, because the location is in the middle of Jambi City and is adjacent to the university. qualified universities such as UNJA, UMBARI and STIKOM. In addition, STAI also competes with universities in the Al-Azhar environment itself. Of course, students or the public prefer one that is more qualified than the Private STAI in the Al-Azhar Integrated Foundation itself.

Based on the results of the observations and interviews of the researchers mentioned above, it can be concluded that customer service quality satisfaction is superior to the Al- 
Ma'rif Private STAI. This can be seen from several aspects of the implementation of national education standards which almost meet the standards. Therefore, it can be said that customer satisfaction analysis gives value to customers such as conducive learning services, the building area where the study is located is far from the noise of motorbikes and cars passing by on the highway. Then the accountability of graduation can compete with students from other universities.

\section{RESULTS AND DISCUSSION}

Based on the background above, it can be concluded that the planning of service quality in the Three Private STAIs in the Kopertais Region XIII Jambi City is in accordance with what has been determined by the government contained in PP no. 19 of 2005 concerning National Education Standards, and also the standards made by Kopertais as supervisors and supervisors of universities in their environment. The implementation of service quality carried out by the Three Private STAIs in the Kopertais Region XIII Jambi City has both implemented the eight standards as specified in the plan. However, there is a very significant difference between Ashanta and Al-Azhar Private STAI and Al-Marif Private STAI. Of the three STAIs, the one that is superior is the Al-Ma'rif Private STAI, with evidence that can be seen from the number of students quite a lot, and the majority of the teaching staff are S2 qualified and some are even S3 qualified.

Service quality satisfaction from Al-Ma'rif's private STAI customers has the advantage of the three Private STAIs that are the targets of researchers, satisfaction indicators such as learning facilities and infrastructure are independent and have their own. In addition, the management of financing is more organized and transparent from the Foundation and the Chairperson of the Foundation to their subordinates. Payment of honorarium for staff and lecturers in accordance with the provisions specified and paid on time. This article discusses Leadership Management in Improving the Quality of Services in Private University. This theme is in line with previous articles including: 1) Leadership Management: (Limakrisna et al., 2016), (Bastari et al., 2020), (Anwar et al., 2020), (Ali et al., 2016), (Djoko Setyo Widodo, P. Eddy Sanusi Silitonga, 2017), (Chauhan et al., 2019), (Elmi et al., 2016); 2) Quality of Services: (Elmi \& Ali, 2017), (Agussalim et al., 2016), and (Prayetno \& Ali, 2020).

\section{CONCLUSION}

The government can give attention and support to private STAIs that do not meet service quality standards, so that they are balanced with other universities. The head of a private STAI who does not meet service standards can try to be even more active, so that the STAI that is led can compete with other private STAIs. On the other hand, private STAIs that already meet the standards will continue to strive to achieve the standards set by the government. 


\section{BIBLIOGRAPHY}

Agussalim, M., Ayu Rezkiana Putri, M., \& Ali, H. (2016). Analysis work discipline and work spirit toward performance of employees (case study tax office Pratama two Padang). International Journal of Economic Research.

Ali, H., Mukhtar, \& Sofwan. (2016). Work ethos and effectiveness of management transformative leadership boarding school in the Jambi Province. International Journal of Applied Business and Economic Research.

Anwar, K., Muspawi, M., Sakdiyah, S. I., \& Ali, H. (2020). The effect of principal's leadership style on teachers' discipline. Talent Development and Excellence.

Bastari, A., -, H., \& Ali, H. (2020). DETERMINANT SERVICE PERFORMANCE THROUGH MOTIVATION ANALYSIS AND TRANSFORMATIONAL LEADERSHIP. International Journal of Psychosocial Rehabilitation. https://doi.org/10.37200/ijpr/v24i4/pr201108

Bardach Engene, A. Pratical Guide For Policy Solving, New York Catham, House Publiskers of Seven Bridges. Press, 2000.

Bruc W. Tuckman, Conducting Education Research, New York: Harcourt Brace 1972.

Communitiess, How to Gather Views on Service Quality Techniques and Tools, http/www Communitiesscoltioand .gov. uk/stellent/group/public/documents/webpages/rics011960.hcap, 2007.

Chauhan, R., Ali, H., \& Munawar, N. A. (2019). BUILDING PERFORMANCE SERVICE THROUGH TRANSFORMATIONAL LEADERSHIP ANALYSIS, WORK STRESS AND WORK MOTIVATION (EMPIRICAL CASE STUDY IN STATIONERY DISTRIBUTOR COMPANIES). Dinasti International Journal of Education

Management And Social Science. https://doi.org/10.31933/dijemss.v1i1.42

Djoko Setyo Widodo, P. Eddy Sanusi Silitonga, \& H. A. (2017). Organizational

Performance : Analysis of Transformational Leadership Style and Organizational

Learning. Saudi Journal of Humanities and Social Sciences.

https://doi.org/10.21276/sjhss.2017.2.3.9

Daryanto, Administrasi dan ManajemenSekolah( Jakarta: RinekaCipta: 2013.

Dede Mulyana, Metode penelitian Kualitatif; Paradigma Baru penelitian Komunikasi dan Ilmu Lainnya, Bandung: Rosda Karya, 2002.

Denis, Forcese and Stepher Richer, Social Research Methode, New Jesrsey, Prantice-Hall Inc.,Eglewood Cliffs, 1973.

Elmi, F., \& Ali, H. (2017). The effect of incentive, training, and career development on productivity of PT. Pelita Cengkareng paper's workers. International Journal of Applied Business and Economic Research.

Elmi, F., Setyadi, A., Regiana, L., \& Ali, H. (2016). Effect of leadership style, organizational culture and emotional intelligence to learning organization: On the Human Resources Development Agency of Law and Human Rights, Ministry of Law and Human Rights. International Journal of Economic Research.

Edward Sallis, Total Qualiti Management in Education,alihbahasa Ahmad Ali RiyadiYokyakarta: Ircisod, 2006.

Eka Prihatin, TeoriAdministrasi Pendidikan, Bandung, CV. Alfabeta, 2011. 
HadariNawawi Metode penelitian Bidang Sosial, Yokyakarta: gajah Mada,1988.

HarbaniPasolong, TeoriAdministrasiPublik, Bandung, CV. Alfabeta, 2010.

Hermawan Wasito, Pengantar Metodologi Peneltian, Jakarta:Gramedia, 1995.

Limakrisna, N., Noor, Z. Z., \& Ali, H. (2016). Model of employee performance: The empirical study at civil servants in government of west java province. International Journal of Economic Research.

Mastuhu, Sistem Pendidikan, Jakarta: Rineka Cipta, 2004.

Matwey Miles dan Huberman, Analisis Data Kualitatif, Jakarta: UI Pres, TT.

Miftah Thoha, KepemimpinandalamManajemenJakarta, Raja Grafindo, 2012

Mustafa Remangi, Pendidikan Islam Tantangan Globalisasi, Yokyakrta: Ar-Ruzz Media, tt.

Nana Syaodihsukmadinata, Ayi Novi Jami'at dan Ahman, PengedalianMutu Pendidikan

SekolahMenengah (Konsep, prinsip, dan Instrumen) ( Bandung, PT. Refikaaditama, 2006.

Nanang Fattah, LandasanManajemen Pendidikan, Bandung: RemajaRosdakarya, 1996.

Prayetno, S., \& Ali, H. (2020). The influence of work motivation, entrepreneurship knowledge and advocate independence on advocate performance. International Journal of Innovation, Creativity and Change.

Ricky W. Griffin, Management, New Delhi: Houghton Miffin Company, 1997.

Robert Kreitner, Management,New Delhi: AITBS Publishers \& Distributors, 1999.

Saefullah, Manajemen Pendidikan Islam, 2012, h. 1Tim DosenAdministrasi Pendidikan UPI, Manajemen Pendidikan, Bandung: Alfabeta, 2010.

Saefullah, Manjemen Pendidikan Islam, Bandung Pustaka Setia, 2012.

SanafiahFaisah, PenelitianKualitatif, Malang: Yayasan Asah, asih, asuh, 1990.

Sedarmayanti, SumberDayaManusia dan ProduktivitasKerja, Bandung, CV. Mandar Maju, 2009.

Shahin, Arash, Servqual, and model of sevice quality Gaps: A Framewock for Determining and priorittizing Crittical factors in Delivering Quality Services. http://www.Qrnconf.com/Docs/0077, pdf, 2007.

Sondang P Siagian, ManajemenSumberDayaManusia, Jakarta : PT BumiAksara. 2008.

Sugiyono, Metode Penelitian Kualitatif, Bandung: Alfabeta, 2008.

Suprapto, Teknik Sampling Untuk Surver dan Eksperimen, Jakarta: Rineka Cipta, 1992.

SyaifulSagala, KemampuanProfesional Guru dan Tenaga Kependidikan( Bandung. CV. Alfabeta, 2009.

Triton PB, MengelolaSumberdayamanusia,Jakarta, Oryza. 2009.

Wagner, Jhon A. III and John R. Hollenbeck. Management OrganizationlBehavior. New Jersey: Englewood Prentice Hall, 1995.

William M. Lindsay dan Joseph A. Petrick, Total Quality and Organization Development, St. Lucie Press, 1997. 